\title{
Influence of ryegrass managements on the physical properties of a Haplohumox
}

\author{
Bruno Vizioli(1), Karina Maria Vieira Cavalieri-Polizeli(1) and Gabriel Barth ${ }^{(2)}$
}

(1)Universidade Federal do Paraná, Campus I, Departamento de Solos e Engenharia Agrícola, Rua dos Funcionários, № 1.540, Juvevê, CEP 80035-050 Curitiba, PR, Brazil. E-mail: brunovizioli@gmail.com, karina_cavalieri@yahoo.com.br (2)Fundação ABC, Rodovia PR-151, Km 288, Caixa Postal 1003, CEP 84166-981 Castro, PR, Brazil. E-mail: gabrielbarth@fundacaoabc.org.br

\begin{abstract}
The objective of this work was to evaluate the influence of ryegrass (Lolium multiflorum) managements on the physical properties of a Haplohumox, and on the yields of corn and of ryegrass cultivated in succession to corn. The experiment was carried out in a randomized complete block design, with three treatments and three replicates, in which treatments were the different managements of ryegrass under no-tillage for silage, soil cover, and grazing. After nine years of management, samples were collected at $0.00-0.05,0.05-0.10,0.10$ 0.20 , and $0.20-0.30-\mathrm{m}$ soil depths, to determine the following soil properties: texture, total organic carbon, soil bulk density, macroporosity, microporosity, total porosity, and resistance to root penetration. The index of structural stability was estimated from texture and total organic carbon data. Maximum soil bulk density and permanent wilting point were also estimated from pedotransfer functions. Corn and ryegrass dry matter yields were determined from plants harvested inside the plot area. Total organic carbon content increased as depth increased. The ryegrass managements in no-tillage system, in succession to corn, does not influence the soil physical properties of a Haplohumox, and maintains high corn and ryegrass yields.
\end{abstract}

Index terms: Lolium multiflorum, no-tillage system, soil physical quality.

\section{Influência de manejos de azevém sobre as propriedades físicas de um Latossolo Bruno}

\begin{abstract}
Resumo - O objetivo deste trabalho foi avaliar a influência de manejos de azevém (Lolium multiflorum) sobre as propriedades físicas de um Latossolo Bruno e sobre a produção de milho e de azevém em sucessão ao milho. O experimento foi realizado em blocos ao acaso, com três tratamentos e três repetições, em que os tratamentos foram os diferentes manejos do azevém, em sistema plantio direto, para silagem, cobertura do solo e pastejo. Após nove anos de manejo, coletaram-se amostras a 0,00-0,05, 0,05-0,10, 0,10-0,20 e 0,20-0,30 m de profundidade do solo, para a determinação dos seguintes atributos: textura, carbono orgânico total, densidade, macroporosidade, microporosidade, porosidade total e resistência à penetração de raízes. O índice de estabilidade estrutural foi estimado a partir dos dados de textura e carbono orgânico total. A densidade máxima do solo e o ponto de murcha permanente também foram estimados a partir de funções de pedotransferência. As produtividades de massa de matéria seca do milho e do azevém foram determinadas a partir da colheita na parcela. O conteúdo de carbono orgânico total aumentou com o aumento da profundidade. Os manejos do azevém em plantio direto, em sucessão ao milho, não influenciam os atributos físicos do Latossolo Bruno e mantêm altas as produtividades de milho e de azevém.
\end{abstract}

Termos para indexação: Lolium multiflorum, sistema plantio direto, qualidade física do solo.

\section{Introduction}

No-tillage system (NT) usually subjects the soil to high-traffic load, soil disturbance in sowing row, and the alternation of summer and winter crops, which may cause soil compaction (Mentges et al., 2016). Compaction is often reported in soils under NT (Moraes et al., 2014, 2016), which can damage the soil physical quality due to air availability, reduction of water and nutrients available to the plants, reducing the volume of soil explored by the roots, as a consequence of the increased bulk density and resistance to root penetration (Silva et al., 2014).

However, some authors report that the presence of straw on the surface, characteristic of NT, can attenuate the effect of reducing the soil physical quality over time (Rosim et al., 2012; Moraes et al., 2016). Rosim et al. (2012) evaluated the resistance to root penetration (RP) in a Hapludox of a clayey texture under different Creative Commons Attribution 4.0 International License 
amounts of millet straw (Pennisetum glaucum) in NT, and concluded that the treatment with greater amount of straw provided less soil RP. According to the authors, the surface straw contributed to dissipate machinery traffic energy, besides promoting increase of soil moisture, which favors the reduction of RP. Despite the benefits resulting from de presence crop residues on the soil, in the region of Campos Gerais, in Paraná state, Brazil (one of the most important dairy basins and the most productive one in Brazil (Paraná, 2016), cattle farmers remove the plants from the soil in the vegetative phase for the production of silage. In these regions, corn (Zea mays) cultivated during the summer is the most used crop for the production of silage (Mendonça et al., 2014). However, in order to keep the soil covered and to obtain extra income during the corn off-season (winter), it is common to sow forage, from which brachiaria (Urochloa spp. Syn. Brachiaria spp.) is the most used one in tropical climates (Mendonça et al., 2014), and ryegrass (Lolium multiflorum Lam.), the most common one in soils of temperate regions (Petean et al., 2010; Auler et al., 2014). Corn-ryegrass succession is largely used for the production of silage in no-till system, in the dairy basin of Castro, PR, Brazil, in which ryegrass has been used by its adaptation to the region's climate, and to provide more than one cut per crop due to tillering and regrowth after the first cut.

Another common practice is to subject the crop to off-season grazing, which allows of cattle to gain weight, and the better use of the soil and crop, which avoid silage production costs (Petean et al., 2010; Mendonça et al., 2014). However, in both grazing and silage production, the soil is subjected to loads that may compromise its physical quality. Auler et al. (2014) assessed the soil physical properties of a clayey Haplohumox after seven years under NT for ryegrass grazing and silage usage, and they did not observe a significant difference between treatments in the bulk density and soil moisture, at $0.00-0.10 \mathrm{~m}$ soil depth. The authors attributed this result to the good structural condition that the treatments promoted to the soil during seven years due to the absence of rotation and to the presence of roots in the surface layer. However, the authors did not assessed the soil physical properties that allow of the specific evaluation of the soil structure. Detailed evaluations of soil physics are necessary to verify the influence of ryegrass management on the physical quality of Haplohumox, mainly on a long term basis.

Therefore, long-term experiments may be the best way to evaluate soil physical attributes in the different uses and managements in NT, since those effects on the attributes can take years to be detected (Reichert et al., 2016) or not detected. In soils managed in stable NT, for which there are no significant attribute variations over time, the soil bulk density and RP tend to decrease because of the total organic carbon (TOC) increment, mainly in the surface layer, due to the presence of straw and to root system preservation of the plants (Auler et al., 2014).

In order to conclude which management systems can be adopted in a given region, it is recommended to evaluate the crop performance and yield. Auler et al. (2014) observed that the uses of ryegrass as coverage, silage, or for grazing purpose in NT promoted the reduction of porosity, and the increase of soil bulk density, concluding that these treatments decreased the soil physical quality; however, these authors did not evaluate the crop yield. In this context, evaluations that disregard the biotic factors can reach partial conclusions about the real influence of these treatments on the crop yield.

The objective of this work was to evaluate the influence of ryegrass management on the physical properties of a Haplohumox and on corn and ryegrass yields.

\section{Materials and Methods}

The studied area is located in the municipality of Castro, Campos Gerais, PR, Brazil (24\%47'53"S, $49^{\circ} 57^{\prime} 42^{\prime \prime} \mathrm{W}$, at $996 \mathrm{~m}$ altitude). The climate of the region, according to the Köppen-Geiger's classification, is temperate humid (Cfb), with occurrences of frost in the winter, and $25^{\circ} \mathrm{C}$ maximum and $5^{\circ} \mathrm{C}$ minimum average annual temperatures. The accumulated rainfall in the agricultural year 2013/2014 is presented in Figure 1. The relief is slightly undulated, and the soil of the experimental area is a typical clayey Dystrophic Haplohumox [Latossolo Bruno distrófico típico, according to the Brazilian soil classification (Santos et al., 2006)]. The soil texture, determined by the densimeter method of Bouyoucos, showed the following characteristics at the layers: $(0.00-0.05 \mathrm{~m})$, $442 \mathrm{~g} \mathrm{~kg}^{-1}$ clay, $128 \mathrm{~g} \mathrm{~kg}^{-1}$ silt, and $430 \mathrm{~g} \mathrm{~kg}^{-1}$ sand; 
(0.05-0.10 m), $478 \mathrm{~g} \mathrm{~kg}^{-1}$ clay, $117 \mathrm{~g} \mathrm{~kg}^{-1}$ silt, and $405 \mathrm{~g}$ $\mathrm{kg}^{-1}$ sand; (0.10-0.20 m) $497 \mathrm{~g} \mathrm{~kg}^{-1}$ clay, $104 \mathrm{~g} \mathrm{~kg}^{-1}$ silt, and $399 \mathrm{~g} \mathrm{~kg}^{-1}$ sand; $(0.20-0.30 \mathrm{~m}), 528 \mathrm{~g} \mathrm{~kg}^{-1}$ clay, 99 $\mathrm{g} \mathrm{kg}^{-1}$ silt, and $373 \mathrm{~g} \mathrm{~kg}^{-1}$ sand.

The soil chemical properties, determined prior to the installation of the experiment in March 2004, were: (at $0.00-0.10 \mathrm{~m}$ soil depth), $4.7 \mathrm{pH}\left(\mathrm{CaCl}_{2}\right), 72 \mathrm{mmol}_{\mathrm{c}}$ $\mathrm{dm}^{-3} \mathrm{H}+\mathrm{Al}, 1 \mathrm{mmol}_{\mathrm{c}} \mathrm{dm}^{-3} \mathrm{Al}, 37 \mathrm{mmol}_{\mathrm{c}} \mathrm{dm}^{-3} \mathrm{Ca}, 10$ $\mathrm{mmol}_{\mathrm{c}} \mathrm{dm}^{-3} \mathrm{Mg}, 4.8 \mathrm{mmol}_{\mathrm{c}} \mathrm{dm}^{-3} \mathrm{~K}, 132.2 \mathrm{mmol}_{\mathrm{c}} \mathrm{dm}^{-3}$ CEC, $85 \mathrm{mg} \mathrm{dm}^{-3} \mathrm{P}, 29 \mathrm{~g} \mathrm{dm}^{-3} \mathrm{TOC}$, and $42 \% \mathrm{~V}$; and (at 0.10-0.20 m soil depth), $4.6 \mathrm{pH}\left(\mathrm{CaCl}_{2}\right), 72 \mathrm{mmol}_{\mathrm{c}} \mathrm{dm}^{-3}$ $\mathrm{H}+\mathrm{Al}, 2 \mathrm{mmol}_{\mathrm{c}} \mathrm{dm}^{-3} \mathrm{Al}, 22 \mathrm{mmol}_{\mathrm{c}} \mathrm{dm}^{-3} \mathrm{Ca}, 8 \mathrm{mmol}_{\mathrm{c}}$ $\mathrm{dm}^{-3} \mathrm{Mg}, 2.7 \mathrm{mmol}_{\mathrm{c}} \mathrm{dm}^{-3} \mathrm{~K}, 104.2 \mathrm{mmol}_{\mathrm{c}} \mathrm{dm}^{-3} \mathrm{CTC}$, $44 \mathrm{mg} \mathrm{dm}^{-3} \mathrm{P}, 24 \mathrm{~g} \mathrm{dm}^{-3} \mathrm{TOC}$, and $31 \% \mathrm{~V}$ according to Auler et al. (2014).

Until the 1960s, the experimental area was under native vegetation; from then on, it has been used for agriculture, with two crops a year, wheat (Triticum aestivum) in the winter and soybean (Glycine max) in teh summer. Soil preparation was conventional, with two plowings and a harrowing, at the $0.00-0.20 \mathrm{~m}$ soil depth, until the set of the experiment in March 2005.

The experiment was carried out with different ryegrass managements under no-till (NT), in succession of corn, in a randomized complete block design with three treatments and three replicates, and each plot occupied an area of $100 \mathrm{~m}^{2}(10 \times 10 \mathrm{~m})$. The treatments consisted of silage ryegrass, ryegrass left as soil cover, and ryegrass for grazing. Lime was surface applied at 5,360 and $8,360 \mathrm{~kg} \mathrm{ha}^{-1}$, in the beginning of the experiment and in March of 2009, respectively. In all treatments, ryegrass and corn were sown in the last fortnight of May, and in the first fortnight of October, respectively. Annually, $20 \mathrm{~kg} \mathrm{ha}^{-1}$ corn seed were sown at seeding depth up to $0.03 \mathrm{~m}$, with $0.80 \mathrm{~m}$ spacing between rows, using a no-till seed-fertilizer.

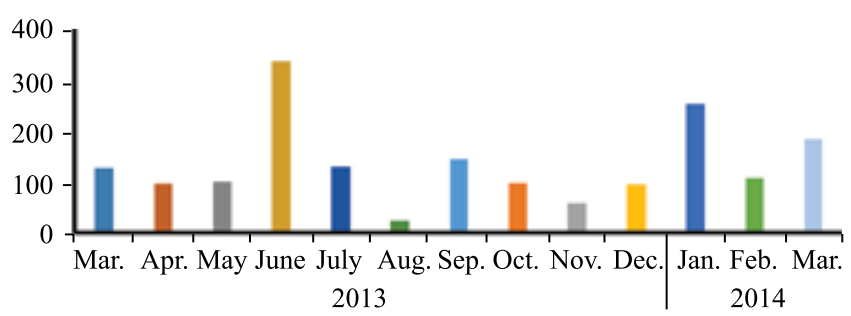

Figure 1. Accumulated rainfall in the evaluation period of the experiment, from March 2013 to March 2014.
Nitrogen fertilization on corn culture was performed with $165 \mathrm{~kg} \mathrm{ha}^{-1}$ on installment, and the first application was $40 \mathrm{~kg} \mathrm{ha}^{-1} 15-30-0 \mathrm{~N}-\mathrm{P}_{2} \mathrm{O}_{5}-\mathrm{K}_{2} \mathrm{O}$, at sowing, and $25-00-25 \mathrm{~N}-\mathrm{P}_{2} \mathrm{O}_{5}-\mathrm{K}_{2} \mathrm{O}$, at the $\mathrm{V} 4$ stage of the culture. Phosphorus and potassium were applied to the planting furrow at $80 \mathrm{~kg} \mathrm{ha}^{-1} \mathrm{P}_{2} \mathrm{O}_{5}$ and $125 \mathrm{~kg}$ $\mathrm{ha}^{-1}$ of $\mathrm{K}_{2} \mathrm{O}$. For the control of weeds $600 \mathrm{~g} \mathrm{ha}^{-1}$ of the herbicide nicosulfuron were applied on plants in the post emergence, at the crop stadium V3.

In February, corn was mechanically harvested for silage, when grains were milky, or solid with starch. The soil was kept in fallow until the sowing of ryegrass, in the first half of May. The ryegrass sowing occurred annually, using a no-till fertilizer, $60 \mathrm{~kg} \mathrm{ha}^{-1}$ seed at $0,03 \mathrm{~m}$ soil depth, and $0,17 \mathrm{~m}$ row spacing. For the ryegrass cultivation, in all harvests, $200 \mathrm{~kg} \mathrm{ha}^{-1}$ of the formulated $\mathrm{N}-\mathrm{P}_{2} \mathrm{O}_{5}-\mathrm{K}_{2} \mathrm{O}$ 10-20-20 were applied as basic fertilization, and $120 \mathrm{~kg} \mathrm{ha}^{-1} \mathrm{~N}$ and $36 \mathrm{~kg} \mathrm{ha}^{-1}$ $\mathrm{K}_{2} \mathrm{O}$ were applied during the tillering phase. The treatment of ryegrass for silage received more $55 \mathrm{~kg}$ $\mathrm{ha}^{-1} \mathrm{~N}$ after the first cut, in order to provide two cuts per crop. Corn-ryegrass succession occurred annually from May 2005 until May 2014, when the experiment completed nine years.

In the treatment of ryegrass for silage, plant cutting occurred when the crop reached about $0.30 \mathrm{~m}$ height, at $0.10 \mathrm{~m}$ above the soil, with a silage machine. In the treatment of ryegrass for soil cover, plants were desiccated with glyphosate (1200 $\left.\mathrm{g} \mathrm{ha}^{-1}\right)$, when plants reached $0.30 \mathrm{~m}$ height, and shoots and roots were kept on the soil until corn planting. In the treatment of ryegrass for grazing, cattle was managed in a rotational grazing system with European dairy cattle (Dutch cattle breed); the animal stocking rate adopted was 3 AU for seven days, or until ryegrass reached a height lower than $0.10 \mathrm{~m}$. Cattle returned to the area at 21-day-intervals. After the last cut of ryegrass for silage, and the last pasture of grazed ryegrass, plants were kept on the soil for 20 days, and then desiccated with glyphosate, as previously described.

After the summer harvest, on March 2014, deformed soil samples were collected at three points in the plot area, in the corn sowing row, at 0.00-0.05, 0.05-0.10, $0.10-0.20$, and $0.20-0.30 \mathrm{~m}$ soil depths. In the same site and layers, undisturbed soil samples were collected in volumetric metal cylinders $\left(\approx 97 \mathrm{~cm}^{3}\right)$, totaling 108 deformed and undisturbed samples. The undisturbed samples were packed and sent to the laboratory, and 
then packed in plastic film and maintained in cold rooms $\left( \pm 5^{\circ} \mathrm{C}\right)$ for 15 days, in the absence of light, until processing. From the deformed samples, the total organic carbon content (TOC) was determined by chemical attack of sodium dichromate in sulfuric medium.

After the sample processing, which had the objective of eliminating the excess soil from the cylinder edges, the undisturbed samples were saturated with water, weighed, and subjected to the potential of $-100 \mathrm{hPa}$ in a Richards chamber. After the equilibrium, the samples were weighed, and subjected to the determination of resistance to root penetration (RP), using a penetrometer with $4 \mathrm{~mm}$ cone diameter, $60^{\circ}$ angle, and $50 \mathrm{~mm}$ stick height. The cone tip was inserted into the center of the undisturbed sample at $0.001 \mathrm{~m} \mathrm{~s}^{-1}$ speed, and the data were obtained by an automatic data acquisition system (Tormena et al., 1998). Then, the samples were dried in an oven at $105^{\circ} \mathrm{C}$, for 24 hours. Soil bulk density $\left(\rho_{\mathrm{S}}\right)$ was obtained by the ratio of dried soil mass and the cylinder volume. Total porosity (TP) was obtained from the difference of saturated soil mass and dried soil mass, divided by the volume of the cylinder. The microporosity (micro) was determined from the difference of the mass of moist soil after the equilibrium at $-100 \mathrm{hPa}$ and the mass of dried soil, divided by the cylinder volume, and macroporosity (macro) by the difference of TP and micro.

The soil relative density $\left(\rho_{\mathrm{R}}\right)$ was determined by the ratio of $\rho_{\mathrm{S}}$ and the maximum soil bulk density $\left(\rho_{M}\right)$. For this, $\rho_{M}$ was estimated by the function $\rho_{\mathrm{M}}=2.03133855-0.00320878 \times \mathrm{OM}-0.00076508 \times$ clay, proposed by Marcolin \& Klein (2011), and estimates $\rho_{\mathrm{M}}$ in function of the clay content and soil TOC, for each analyzed sample. The function has been successful in the $\rho_{\mathrm{M}}$ estimation due to its accuracy and ease of obtaining the estimated data (Drescher et al., 2016).

The volume of available water (AW) was the volume of water in the soil between the field capacity (FC) and the permanent wilting point (PWP). The FC was determined at the potential of $-100 \mathrm{hPa}$ (Haise et al., 1955; Tormena et al., 1998; Petean et al., 2010; Moraes et al., 2016), while PWP was estimated by the function, proposed by Klein et al. (2010), $\mathrm{PWP}=0.0003 \times$ clay +0.0118 , which has been used to estimate the PWP, considering that the determination, when done in the chamber of Richards, can take months for clay soils.
The soil structural stability was evaluated by the structural index (SI), according to the equation proposed by Reynolds et al. $(2009) \mathrm{SI}=[(\mathrm{TOC} \times 1.724) /$ (clay+silt)] $\times 100$, in which TOC is measured in $\mathrm{g} \mathrm{dm}^{-3}$, clay and silt contents are measured in $\mathrm{g} \mathrm{kg}^{-1}$, and 1.724 is the constant to convert TOC into soil organic matter $(\mathrm{OM})$.

The data were subjected to the normality test of Shapiro-Wilk and to the analysis of variance. When statistical difference was detected, the comparison between means was performed using the Tukey's test at $5 \%$ probability.

\section{Results and Discussion}

The total organic carbon (TOC) levels were the same among treatments at $0.00-0.05 \mathrm{~m}$ soil depth; even for ryegrass left as soil cover, there was no greater contribution of TOC in this layer (Table 1). The absence of difference of TOC between treatments could be associated with the higher rate of straw decomposition in the first centimeters of the soil, since plant densities of corn and ryegrass were similar, providing the same addition of TOC in the $0.00-0.05 \mathrm{~m}$ (Piva et al., 2012). However, at $0.05-0.10 ; 0.10-0.20$, and $0.20-0.30 \mathrm{~m}$ soil depths, the TOC levels were affected by treatments.

Ryegrass for silage and ryegrass left as soil cover provided a higher-TOC content at $0.05-0.10 \mathrm{~m}$ soil depth in comparison to ryegrass for grazing, possibly due to the higher volume of roots maintained in this layer (Table 1). The highest volume of roots of ryegrass left as soil cover is due to the presence of straw on the surface; and, in ryegrass for silage, the highest root volume was due to the fertilization of the cover to produce two cuts. Thus, there was a greater mass of roots in these treatments, which were the main sources of TOC in depth (Shahbaz et al., 2017).

The grazing ryegrass showed the lowest-TOC value in comparison to the other treatments, probably due to animal trampling action, which may have impaired growth and root development between 0.05-0.10 m depth. Generally, this layer suffers most by trampling, which affects the soil structure (Debiasi \& Franchini, 2012), however, grazing systems stimulate root growth in depth (Petean et al., 2010; Oliveira et al., 2016), increasing TOC in soil deeper layers. This was observed at $0.10-0.20$ and $0.20-0.30 \mathrm{~m}$ soil depths,

Pesq. agropec. bras., Brasília, v.53, n.8, p.952-960, Aug. 2018 DOI: $10.1590 / \mathrm{S} 0100-204 X 2018000800010$ 
where there was no difference between ryegrass for silage and grazing ryegrass (Table 1).

These results are due to the higher fertilization of ryegrass for silage and grazed ryegrass, both stimulating the growth and development of roots. TOC in silage ryegrass and ryegrass left as soil cover were not different below $0.05 \mathrm{~m}$ depth. In this case, ryegrass straw maintained in ryegrass left on the soil surface promoted a TOC increase similar to that in ryegrass for silage, in this layer, which resulted in the increase of nutrient availability due to a greater fertilization. Nevertheless, root growth stimulus due to grazing provided a higher-TOC increment in the deeper layers, corroborating the findings by Petean et al. (2010).

The ryegrass managements provided an increase of TOC content in Haplohumox in comparison to the contents determined in 2004 of $29 \mathrm{~g} \mathrm{dm}^{-3}$ (at $0.00-0.10 \mathrm{~m}$ soil depth) and $24 \mathrm{~g} \mathrm{dm}^{-3}$ (at $0.10-0.20$ soil depth), before the experiment installation, resulting in an increasing of COT content of 10 and $5 \%$, at $0.00-0.10 \mathrm{~m}$ and
0.10-0.20 m soil depths, respectively. This increase were attributed to the maintenance of the root system of ryegrass and corn into the soil over nine years of experiment, and due to the absence of tillage provided by NT.

There were no differences for mean values of $\rho_{\mathrm{S}}$ among treatments at all evaluated soil depths, which evidences that the traffic of machinery and animal trampling on ryegrass for silage and on grazed ryegrass, respectively, did not compromise $\rho_{\mathrm{S}}$ in relation to $\mathrm{C}$ that received less load. Another factor that should be considered, in order to avoid significant differences in $\rho_{\mathrm{S}}$, is the high-TOC value on the soil surface layer (Auler et al., 2014). It is known that TOC reduces $\rho_{\mathrm{S}}$ of soils because it dissipates the energy of the machinery traffic and animal trampling (Reichert et al., 2016), and contributes to soil structuring, aggregation of mineral particles, and formation of more stable aggregates (Oliveira et al., 2016).

Table 1. Mean values of total organic carbon (TOC), soil bulk density $\left(\rho_{\mathrm{S}}\right)$, estimated maximum density $\left(\rho_{\mathrm{M}}\right)$, relative soil density $\left(\rho_{\mathrm{R}}\right)$, macroporosity (Macro); microporosity (Micro), total porosity (TP), available water (AW), and structural index (SI) of a Haplohumox, subjected to different ryegrass managements, in a no-tillage system ${ }^{(1)}$.

\begin{tabular}{|c|c|c|c|c|c|c|c|c|c|}
\hline Treatment & $\begin{array}{c}\text { TOC } \\
\left(\mathrm{g} \mathrm{dm}^{-3}\right)\end{array}$ & $\begin{array}{c}\rho_{\mathrm{S}} \\
-----(\end{array}$ & $\begin{array}{c}\rho_{M} \\
\text { 3)----- }\end{array}$ & $\rho_{\mathrm{R}}$ & \multicolumn{2}{|c|}{$-----\left(\mathrm{m}^{3} \mathrm{~m}^{-3}\right)------$} & \multicolumn{2}{|c|}{------(m $\left(\mathrm{m}^{3} \mathrm{~m}^{-3}\right)-----$} & $\begin{array}{c}\text { SI } \\
(\%)\end{array}$ \\
\hline & \multicolumn{9}{|c|}{$0.00-0.05 \mathrm{~m}$} \\
\hline Ryegrass for silage & $43.90^{\mathrm{ns}}$ & $1.34^{\mathrm{ns}}$ & $1.56 \mathrm{ab}$ & $0.86^{\mathrm{ns}}$ & $0.09^{\mathrm{ns}}$ & $0.43^{\mathrm{ns}}$ & $0.52^{\text {ns }}$ & $0.29^{\text {ns }}$ & $13,16^{\mathrm{ns}}$ \\
\hline Ryegrass as cover & 45.83 & 1.28 & $1.59 \mathrm{a}$ & 0.81 & 0.11 & 0.42 & 0.53 & 0.29 & 13,63 \\
\hline Ryegrass for grazing & 43.86 & 1.24 & $1.52 \mathrm{~b}$ & 0.81 & 0.10 & 0.41 & 0.51 & 0.26 & 13,33 \\
\hline $\mathrm{CV}(\%)$ & 4.15 & 8.69 & 2.58 & 9.35 & 31.93 & 12.42 & 9.26 & 21.05 & 4,98 \\
\hline \multirow[t]{2}{*}{ MSD } & 2.17 & 0.13 & 0.05 & 0.09 & 0.04 & 0.06 & 0.06 & 0.07 & 2,55 \\
\hline & \multicolumn{9}{|c|}{$0.05-0.10 \mathrm{~m}$} \\
\hline Ryegrass for silage & $33.96 \mathrm{a}$ & $1.32^{\mathrm{ns}}$ & $1.57^{\mathrm{ns}}$ & $0.84^{\mathrm{ns}}$ & $0.09^{\mathrm{ns}}$ & $0.40^{\mathrm{ns}}$ & $0.49^{\text {ns }}$ & $0.25^{\text {ns }}$ & $10,33^{\mathrm{ns}}$ \\
\hline Ryegrass as cover & $34.90 \mathrm{a}$ & 1.34 & 1.56 & 0.87 & 0.10 & 0.40 & 0.50 & 0.24 & 9,67 \\
\hline Ryegrass for grazing & $31.70 \mathrm{~b}$ & 1.37 & 1.56 & 0.88 & 0.11 & 0.41 & 0.52 & 0.24 & 8,80 \\
\hline $\mathrm{CV}(\%)$ & 5.22 & 4.50 & 1.57 & 4.42 & 31.39 & 6.82 & 5.54 & 12.30 & 8,99 \\
\hline \multirow[t]{2}{*}{ MSD } & 2.06 & 0.07 & 0.03 & 0.05 & 0.04 & 0.03 & 0.03 & 0.04 & 3,09 \\
\hline & \multicolumn{9}{|c|}{$0.10-0.20 \mathrm{~m}$} \\
\hline Ryegrass for silage & $31.23 \mathrm{a}$ & $1.34^{\mathrm{ns}}$ & $1.56^{\mathrm{ns}}$ & $0.86^{\mathrm{ns}}$ & $0.10^{\mathrm{ns}}$ & $0.41^{\mathrm{ns}}$ & $0.51^{\mathrm{ns}}$ & $0.25^{\mathrm{ns}}$ & $9,09^{\mathrm{ns}}$ \\
\hline Ryegrass as cover & $28.46 b$ & 1.30 & 1.56 & 0.83 & 0.12 & 0.39 & 0.51 & 0.23 & 8,65 \\
\hline Ryegrass for grazing & $28.70 \mathrm{ab}$ & 1.31 & 1.54 & 0.85 & 0.12 & 0.39 & 0.51 & 0.23 & 9,13 \\
\hline $\mathrm{CV}(\%)$ & 7.73 & 3.43 & 2.47 & 4.86 & 26.47 & 9.03 & 5.53 & 15.40 & 13,77 \\
\hline \multirow[t]{2}{*}{ MSD } & 2.68 & 0.05 & 0.04 & 0.05 & 0.03 & 0.04 & 0.03 & 0.04 & 2,71 \\
\hline & \multicolumn{9}{|c|}{$0.20-0.30 \mathrm{~m}$} \\
\hline Ryegrass for silage & $25.33 \mathrm{ab}$ & $1.27^{\mathrm{ns}}$ & $1.55^{\mathrm{ns}}$ & $0.82^{\mathrm{ns}}$ & $0.11^{\mathrm{ns}}$ & $0.41^{\mathrm{ns}}$ & $0.52^{\mathrm{ns}}$ & $0.24^{\mathrm{ns}}$ & $6,95^{\mathrm{ns}}$ \\
\hline Ryegrass as cover & $22.70 b$ & 1.25 & 1.55 & 0.81 & 0.15 & 0.40 & 0.55 & 0.23 & 6,22 \\
\hline Ryegrass for grazing & $26.23 \mathrm{a}$ & 1.26 & 1.54 & 0.82 & 0.13 & 0.39 & 0.52 & 0.22 & 7,25 \\
\hline $\mathrm{CV}(\%)$ & 10.20 & 4.40 & 2.19 & 4.16 & 24.70 & 7.93 & 6.25 & 12.75 & 12,41 \\
\hline MSD & 2.97 & 0.06 & 0.04 & 0.04 & 0.04 & 0.04 & 0.04 & 0.03 & 1,92 \\
\hline
\end{tabular}

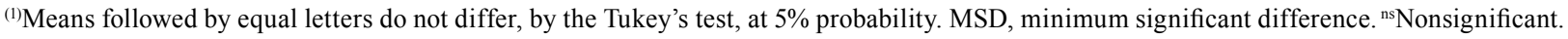


Ryegrass managements did not promote significant differences on macro- and microporosity and on TP of the soil, in all evaluated layers (Table 1). Macroporosity values ranged from 0.09 to $0.15 \mathrm{~m}^{3} \mathrm{~m}^{-3}$, maintaining sufficient porosity for the water drainage and aeration of the root system. From these results, it may be inferred that ryegrass managements did not affect these attributes because the root system of the crops was maintained in the soil during the whole period. This fact may be explained by the existence of biopores formed by root decomposition that promotes the increase and maintenance of macropores. Contrary to what has been frequently reported for soils under NT, as caused by the absence of tillage, combined with the intense traffic of machinery in the soil (Chen \& Weil, 2011). However, Silva et al. (2014) evaluated the physical properties of a clayey Haplohumox $\left(595 \mathrm{~g} \mathrm{~kg}^{-1}\right.$ clay), managed in NT with a crop-livestock integration for 21 months, and concluded that the system caused no significant changes on the attributes after this period.

Auler et al. (2014) evaluated the soil physical properties after seven years of implantation of this same experiment, and also observed no significant differences on the macroporosity, microporosity, and TP between treatments. However, the authors observed lower values of macroporosity than those determined in the present study $\left(0.08-0.12 \mathrm{~m}^{3} \mathrm{~m}^{-3}\right)$, which evidences that this attribute had a small increment over time, with average values very close to or above the limit of $0.10 \mathrm{~m}^{3} \mathrm{~m}^{-3}$, which does not compromise the physical quality of the as for soil aeration. The rotational grazing system, as it happened in this experiment, has a little, negative impact on the physical quality of the soil because it subjects the soil to the load for short periods, providing recovery of eventual losses during fallow (Kuntz et al., 2013). These authors concluded that this type of grazing did not compact a typical clayey dystrophic Hapludox (585 $\mathrm{g} \mathrm{kg}^{-1}$ clay) conducted for 12 years in NT.

The estimated $\rho_{\mathrm{M}}$ showed difference only at the 0.00-0.05 m soil depth (Table 1). The low amplitude of this variable $\left(0.07 \mathrm{~kg} \mathrm{dm}^{-3}\right)$ has been reported and attributed to high-TOC levels in soils (Luciano et al., 2012), mainly for soils under NT.

The managements did not affect the relative soil bulk density $\left(\rho_{R}\right)$ of layers, and the mean values of $\rho_{R}$ within the range considered ideal for plant development is 0.80-0.90 (Marcolin \& Klein, 2011;
Drescher et al., 2016). Low values of $\rho_{R}$, that means very loose soils, can compromise the water retention and soil-seed contact, reducing the plant growth and, consequently, the productivity (Mentges et al., 2016). Drescher et al. (2016) evaluated the $\rho_{R}$ of a typical clayey dystrophic Hapludox, under NT, cultivated with corn-wheat succession for 27 years, using the same methods adopted in the present study. These authors observed that $\rho_{\mathrm{R}}$ up until 0.89 did not compromise the development of plants, mainly the wider and aggressive root system of grass, in comparison to other agricultural crops, such as soybean.

The managements did not promote differences for soil AW, despite ryegrass left as cover and grazed ryegrass that improved TOC content at $0.20-0.30 \mathrm{~m}$ soil depth; and no higher AW volume was observed in any treatment (Table 1). The observed result can be attributed to the use of two species of plants (corn and ryegrass) only. According to Bhattacharyya et al. (2006), cultivation systems with higher-plant diversity confer a greater availability of water to plants. Moraes et al. (2016) did not observe significant differences in the AW of a very clayey dystroferric Hapludox (755 $\mathrm{g} \mathrm{kg}^{-1}$ clay), on two NT conducted over 24 years (wheat-soy and corn-oats), attributing the results to the presence of two species, provided by the succession of crops. The authors inferred that a system of crop rotation (with great plant diversity) would be more beneficial to increase soil AW than crop succession.

In the present study, AW values evidence that the physical quality of the Haplohumox nine years after was not compromised. According to Reynolds et al. (2007, 2009), AW higher than $0.20 \mathrm{~m}^{3} \mathrm{~m}^{-3}$ is indicative of soils with good physical quality, and AW above this value did not compromise the crop development and is indicative that the management did not affect the soil structure to the point of compromising the water availability to the plants. The high-TOC content at $0.00-0.05 \mathrm{~m}$ soil depth may have favored the result observed in the present study, as the TOC favors the water retention, either by retaining water molecules on its specific surface, or by improving the soil structure and aggregation (Saxton \& Rawls, 2006). Thus, it can be inferred that soils with high levels of TOC in the upper layers can show AW volume similar to that of the deeper layers.

The SI did not show statistical difference among the treatments in all studied layers (Table 1). As SI 
is an indicator of risk of erosion, the structure of the Haplohumox is stable. According to Reynolds et al. (2009), SI higher than 7\% is indicative of soils with an optimal structure stability and "low risk of erosion". Although the SI values at $0.20-0.30 \mathrm{~m}$ soil depth are lower than $7 \%$, indicating "moderate risk of erosion", these results have a little, practical effect, as the layer $0.20-0.30 \mathrm{~m}$ is little affected by NT operations in relation to the risk of erosion. In addition, SI values lower than $7 \%$, at $0.20-0.30 \mathrm{~m}$ soil depth are attributed to the lower amount of TOC in this layer, which influences the SI.

The RP determined at the field capacity did not show significant differences between the treatments, at the different layers studied (Figure 2). The values observed in the present study are below the critical limit for the development, which is $3.5 \mathrm{MPa}$. This value has been used as a limiting factor for root growth, in soils under NT (Moraes et al., 2014; Silva et al., 2014), due to the presence of biopores that favor growth of roots with low-mechanical resistance (Moraes et al., 2017). In a dystroferric Hapludox, Moraes et al. (2014) evaluated the effect of different RP values on the crop productivity in two NT (wheat-soy and oat-corn), and concluded that the PR of $3.5 \mathrm{MPa}$ can be adopted as a limiting factor to root growth in soils with water contents close to that of the field capacity.

Higher-RP values in the upper layers can be attributed to the greater cohesive strength and greater internal resistance of the aggregates, which are common in NT. Moraes et al. (2017) pointed out that, over the years, soils under NT tend to have a harder structure because

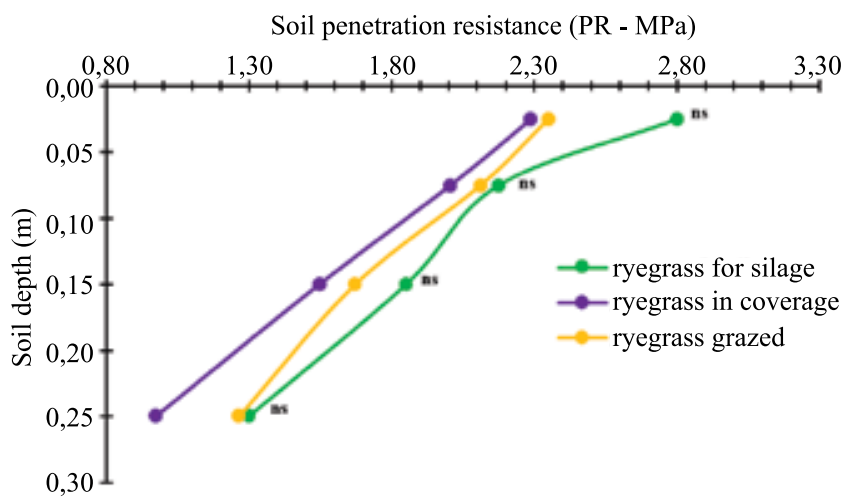

Figure 2. Mean values of soil resistance to penetration (RP) at field capacity, in a Haplohumox subjected to different ryegrass managements in no-tillage system. ${ }^{\text {ns Nonsignificant }}$ difference, by the Tukey's test, at 5\% probability. of the particles arrangement, absence of tillage, and better aggregation that result from the contribution of TOC. This fact can promote high values of RP even under conditions of low $\rho$ s and high water content.

The dry matter mass (DMS) yield of ryegrass was lower in the grazed ryegrass than in the silage ryegrass and ryegrass for cover (Table 2). Grazing systems tend to have lower yields of DMS in comparison to silage systems, since selective pasture by the cattle, which maintains the leaf area, reducing the tillering rate of ryegrass and, consequently, the DMS (Barth Neto et al., 2014). The ryegrass yield in the present work was superior to that determined by Barth Neto et al. (2014) in a medium-textured Paleudult, in the state of Rio Grande do Sul, Brazil, under NT. Although ryegrass grazed showed the lowest-DMS value, it did not compromise the development of cattle, and did not cause damages to the production system.

The DMS of corn was not significant among managements, showing values of $11,760-17,260 \mathrm{~kg}$ $\mathrm{ha}^{-1}$, as also obtained by Mendonça et al. (2014), due to the fact that the sowing season and fertilization occurred according to the recommendation for the crop during all harvests (Piva et al., 2012; Auler et al., 2014). According to Oliveira et al. (2011), corn for silage productivity has a great influence from the corn cutting height; these authors evaluated the silage yield of several corn hybrids produced in a dystroferric Hapludox, in Maringá, PR, Brazil, and obtained values from $14,560 \mathrm{~kg} \mathrm{ha}^{-1}$, when the cut occurred at $15 \mathrm{~cm}$, and $13,000 \mathrm{~kg} \mathrm{ha}^{-1}$, with the at $0.35 \mathrm{~m}$ height.

Some physical factors that directly limit the root growth (water availability, resistance to penetration, and aeration) did not reach critical values in the present study, which may have favored the high-crop

Table 2. Mean values of dry matter mass yield (DMS) of ryegrass (Lolium multiflorum) and corn (Zea mays), determined in the crop season of 2013/2014, in a Haplohumox $^{(1)}$.

\begin{tabular}{lcc}
\hline Treatment & Ryegrass & Corn \\
& $--------\left(\mathrm{kg} \mathrm{ha}^{-1}\right)$ & $------{ }^{\mathrm{ns}}$ \\
\hline Ryegrass for silage & $5,638 \mathrm{a}$ & $15,7700^{\mathrm{s}}$ \\
Ryegrass as cover & $5,151 \mathrm{a}$ & 15,664 \\
Ryegrass for grazing & $3,719 \mathrm{~b}$ & 15,558 \\
\hline Coefficient of variation (\%) & 8.06 & 14.95 \\
\hline
\end{tabular}

(1)Means followed by equal letters, in the columns, do not differ, by Tukey's test, at $5 \%$ probability. ${ }^{\text {ns }}$ Nonsignificant. 
productivity. Thus, the management of ryegrass for cover, grazing, or silage, compromises neither the soil physical quality nor the crop development, favoring the increase of TOC and improvement of soil structure.

\section{Conclusions}

1. The ryegrass managements in no-tillage system, in succession to corn, increment the total organic carbon in depth of a Haplohumox.

2. The ryegrass managements in no-tillage system, in succession to corn, does not influence the soil physical properties of a Haplohumox.

3. The ryegrass managements in no-tillage system, in succession to corn in a Haplohumox, maintain highcorn and ryegrass yields.

\section{Acknowledgments}

To Coordenação de Aperfeiçoamento de Pessoal de Nível Superior (Capes), for scholarship granted.

\section{References}

AULER, A.C.; MIARA, S.; PIRES, L.F.; FONSECA, A.F. da; BARTH, G. Soil physico-hydrical properties resulting from the management in integrated production systems. Revista Ciência Agronômica, v.45, p.976-989, 2014. DOI: 10.1590/S180666902014000500013 .

BARTH NETO, A.; SAVIAN, J.V..; SHONS, R.M.T.; BONNET, O.J.F.; CANTO, M.W. do; MORAES, A. de; LEMAIRE, G.; CARVALHO, P.C. de F. Italian ryegrass establishment by selfseeding in integrated crop-livestock systems: effects of grazing management and crop rotation strategies. European Journal of Agronomy, v.57, p.77-83, 2014. DOI: 10.1016/j.eja.2014.04.005.

BHATTACHARYYA, R.; PRAKASH, V.; KUNDU, S.; GUPTA, H.S. Effect of tillage and crop rotations on pore size distribution and soil hydraulic conductivity in sandy clay loam soil of the Indian Himalayas. Soil \& Tillage Research, v.86, p.129-140, 2006. DOI: 10.1016/j.still.2005.02.018.

CHEN, G.; WEIL, R.R. Root growth and yield of corn as affected by soil compaction and cover crops. Soil \& Tillage Research, v.117, p.17-27, 2011. DOI: 10.1016/j.still.2011.08.001.

DEBIASI, H.; FRANCHINI, J.C. Atributos físicos do solo e produtividade da soja em sistema de integração lavoura-pecuária com braquiária e soja. Ciência Rural, v.42, p.1180-1186, 2012. DOI: $10.1590 / \mathrm{S} 0103-84782012000700007$.

DRESCHER, M.S.; REINERT, D.J.; DENARDIN, J.E.; GUBIANI, P.I.; FAGANELLO, A.; DRESCHER, G.L. Duração das alterações em propriedades fisico-hídricas de Latossolo argiloso decorrentes da escarificação mecânica. Pesquisa
Agropecuária Brasileira, v.51, p.159-168, 2016. DOI: 10.1590/ S0100-204X2016000200008.

HAISE, H.R.; HAAS, H.J.; JENSEN, L.R. Soil moisture studies of some Great Plains soils: II. Field capacity as related to $1 / 3$-atmosphere percentage, and "minimum point" as related to 15- and 26-atmosphere percentages. Soil Science Society of America Journal, v.19, p.20-25, 1955. DOI: 10.2136/ sssaj1955.03615995001900010005x.

KLEIN, V.A.; BASEGGIO, M.; MADALOSSO, T.; MARCOLIN, C.D. Textura do solo e a estimativa do teor de água no ponto de murcha permanente com psicrômetro. Ciência Rural, v.40, p.1550-1556, 2010. DOI: 10.1590/S0103-84782010005000110.

KUNTZ, M.; GONÇALVES, A.D.M. de A.; REICHERT, J.M.; GUIMARÃES, R.M.L.; REINERT, D.J.; RODRIGUES, M.F. Compactação do solo na integração soja-pecuária de leite em Latossolo argiloso com semeadura direta e escarificação. Revista Brasileira de Ciência do Solo, v.37, p.1699-1708, 2013. DOI: 10.1590/S0100-06832013000600026.

LUCIANO, R.V.; ALBUQUERQUE, J.A.; COSTA, A. da; BATISTELLA, B.; WARMLING, M.T. Atributos físicos relacionados à compactação de solos sob vegetação nativa em região de altitude no Sul do Brasil. Revista Brasileira de Ciência do Solo, v.36, p.1733-1744, 2012. DOI: 10.1590/S010006832012000600007.

MARCOLIN, C.D.; KLEIN, V.A. Determinação da densidade relativa do solo por uma função de pedotransferência para a densidade do solo máxima. Acta Scientiarum. Agronomy, v.33, p.349-354, 2011. DOI: 10.4025/actasciagron.v33i2.6120.

MENDONÇA, V.Z. de; MELLO, L.M.M. de; PEREIRA, F.C.B.L.; SILVA, J.O. da R.; YANO É.H. Corn production for silage intercropped with forage in the farming-cattle breeding integration. Engenharia Agrícola, v.34, p.738-745, 2014. DOI: 10.1590/S0100-69162014000400013.

MENTGES, M.I.; REICHERT, J.M.; RODRIGUES, M.F.; AWE, G.O.; MENTGES, L.R. Capacity and intensity soil aeration properties affected by granulometry moisture, and structure in no-tillage soils. Geoderma, v.263, p.47-59, 2016. DOI: 10.1016/j. geoderma.2015.08.042.

MORAES, M.T. de; DEBIASI, H.; CARLESSO, R.; FRANCHINI, J.C.; SILVA, V.R. da; LUZ, F.B. da. Age-hardening phenomena in an oxisol from the subtropical region of Brazil. Soil \& Tillage Research, v.170, p.27-37, 2017. DOI: 10.1016/j.still.2017.03.002.

MORAES, M.T. de; DEBIASI, H.; CARLESSO, R.; FRANCHINI, J.C.; SILVA, V.L. da; LUZ, F.B. da. Soil physical quality on tillage and cropping systems after two decades in the subtropical region of Brazil. Soil \& Tillage Research, v.155, p.351-362, 2016. DOI: 10.1016/j.still.2015.07.015.

MORAES, M.T. de; DEBIASI, H.; CARLESSO, R.; FRANCHINI, J.C.; SILVA, V.R. da. Critical limits of soil penetration resistance in a Rhodic Eutrudox. Revista Brasileira de Ciência do Solo, v.38, p.288-298, 2014. DOI: 10.1590/S0100-06832014000100029.

OLIVEIRA, F.C.L. de; JOBIM, C.C.; SILVA, M.S. da; CALIXTO JUNIOR, M.; BUMBIERIS JUNIOR, V.H.; ROMAN, J. Produtividade e valor nutricional da silagem de híbridos de milho em diferentes alturas de colheita. Revista Brasileira 
de Zootecnia, v.40, p.720-727, 2011. DOI: 10.1590/S151635982011000400004 .

OLIVEIRA, S.P.; CÂNDIDO, M.J.D.; WEBER, O.B.; XAVIER, F.A.S.; ESCOBAR, M.E.O.; OLIVEIRA, T.S. Conversion of forest into irrigated pasture II. Changes in the physical properties of the soil. Catena, v.143, p.70-77, 2016. DOI: 10.1016/j. catena.2016.03.016.

PETEAN, L.P.; TORMENA, C.A.; ALVES, S.J. Intervalo hídrico ótimo de um Latossolo Vermelho distroférrico sob plantio direto em sistema de integração lavoura-pecuária. Revista Brasileira de Ciência do Solo, v.34, p.1515-1526, 2010. DOI: 10.1590/S010006832010000500004.

PIVA, J.T.; DIECKOW, J.; BAYER, C.; ZANATTA, J.A.; MORAES, A. de; PAULETTI, V.; TOMAZI, M.; PERGHER, M. No-till reduces global warming potential in a subtropical Ferralsol. Plant Soil, v.361, p.359-373, 2012. DOI: 10.1007/ s11104-012-1244-1.

REICHERT, J.M.; ROSA, V.T. da; VOGELMANN, E.S.; ROSA, D.P. da; HORN, R.; REINERT, D.J.; SATTLER, A.; DENARDIN, J.E. Conceptual framework for capacity and intensity physical soil properties affected by short and long-term (14 years) continuous no-tillage and controlled traffic. Soil \& Tillage Research, v.158, p.123-136, 2016. DOI: 10.1016/j.still.2015.11.010.

REYNOLDS, W.D.; DRURY, C.F.; TAN, C.S.; FOX, C.A.; YANG, X.M. Use of indicators and pore volume-function characteristics to quantify soil physical quality. Geoderma, v.152, p.252-263, 2009. DOI: 10.1016/j.geoderma.2009.06.009.

REYNOLDS, W.D.; DRURY, C.F.; YANG, X.M.; FOX, C.A.; TAN, C.S.; ZHANG, T.Q. Land management effects on the near-surface physical quality of a clay loam soil. Soil \& Tillage Research, v.96, p.316-330, 2007. DOI: 10.1016/j.still.2007.07.003.

ROSIM, D.C.; DE MARIA, I.C.; SILVA, R.L. e; SILVA A.P. da. Compactação de um latossolo vermelho distroférrico com diferentes quantidades e manejos de palha em superfície. Bragantia, v.71, p.502-508, 2012. DOI: 10.1590/S000687052013005000003 .

SANTOS, H.G. dos; JACOMINE, P.K.T.; ANJOS, L.H.C. dos; OLIVEIRA, V.A. de; OLIVEIRA, J.B. de; COELHO, M.R.; LUMBRERAS, J.F.; CUNHA, T.J.F. (Ed.). Sistema brasileiro de classificação de solos. 2.ed. Rio de Janeiro: Embrapa Solos, 2006. 306p.

SAXTON, K.E.; RAWLS, W.J. Soil water characteristic estimates by texture and organic matter for hydrologic solutions. Soil Science Society of American Journal, v.70, p.1569-1578, 2006. DOI: $10.2136 /$ sssaj2005.0117.

PARANÁ. Secretaria do Estado de Agricultura e do Abastecimento. Departamento de Economia Rural. Leite: Análise da Conjuntura Agropecuária: ano 2015/16. Curitiba: Secretaria do Estado da Agricultura e do Abastecimento, 2016. 15p. Available at: <http://www.agricultura.pr.gov.br/arquivos/ File/deral/Prognosticos/2016/bovinocultura_de_leite_2016.pdf $>$. Accessed on: Ago. 162017.

SHAHBAZ, M.; KUZYAKOV, Y.; HEITKAMP, F. Decrease of soil organic matter stabilization with increasing inputs: mechanisms and controls. Geoderma, v.304, p.76-82. 2017. DOI: 10.1016/j.geoderma.2016.05.019.

SILVA, H.A. da; MORAES, A. de; CARVALHO, P.C. de F.; FONSECA, A.F. da; CAIRES, E.F.; DIAS, C.T. dos S. Chemical and physical soil attributes in integrated crop-livestock system under no-tillage. Revista Ciência Agronômica, v.45, p.946-955, 2014. Número especial. DOI: 10.1590/S1806-66902014000500010.

TORMENA, C.A.; SILVA, A.P.; LIBARDI, P.L. Caracterização do intervalo hídrico ótimo de um Latossolo Roxo sob plantio direto. Revista Brasileira de Ciência do Solo, v.22, p.573-581, 1998. DOI: 10.1590/S0100-06831998000400002.

Received on June 9, 2017 and accepted on November 17, 2017 